\title{
O corpo no cinema silencioso em Béla Balázs e F.W. Murnau
}

\author{
CLÊMIE FERREIRA BLAUD
}

Clêmie Ferreira Blaud é doutoranda em Ética e Filosofia Política (FFLCH-USP) com bolsa Fapesp, mestre em Estética e Filosofia da Arte, bacharelado e licenciatura em Filosofia pela mesma universidade com período de intercâmbio na Université de Paris-Sourbonne IV e bacharelado em Comunicação Social com Habilitação em Cinema (ECA-USP). Dedica-se, atualmente, à pesquisa acadêmica sobre questões das mulheres e de gêneros, partindo do pensamento de Marie de Gournay, autora do século XVII, cujas ideias alcançam a perspectiva do feminismo contemporâneo. Desenvolve atividade artística com o cinema experimental independente buscando refletir sobre as relações entre ética e estética.

Afiliação: Universidade de São Paulo - USP

Lattes: http://lattes.cnpq.br/7648505628561016

Orcid: https://orcid.org/0000-0002-7848-9219

ouvirouver Uberlândia v. 16 n. 1 p. 202-216 jan. |jun. 2020 
- RESUMO

O objetivo deste artigo é estabelecer relações entre o pensamento do filósofo húngaro Béla Balázs e alguns filmes do cineasta alemão F.W. Murnau no que concerne aos estudos sobre o corpo no cinema silencioso. Para Balázs, gestos e expressões faciais constroem uma linguagem, possibilitando a compreensão do destino das personagens. A linguagem do corpo no cinema mudo relaciona-se, por um lado, com alíngua do homem em seu estado original; por outro, com as poses e expressões já pesquisadas em outras formas de artes: cênicas e visuais. Alguns filmes de Murnau servem de exemplo para pensar sobre essas questões. Trata-se de buscar uma interface horizontal entre filosofia e arte,considerando seu modo de coexistência no período em que o cinema não falava.

\section{- PALAVRAS-CHAVE}

BélaBalázs,F.W. Murnau,Cinema, História das artes, Estética.

\section{ABSTRACT}

The aim of this article is to establish relations between the thinking of the Hungarian philosopher Béla Balázs and some films by the German filmmaker F.W. Murnau regarding the studies about the body in the thesilent cinema. For Balázs, gestures and facial expressions construct a language of body, making possible the understanding of the characters's destiny. The language of the body in the silent film is related, on the one hand, with mankind's language in its original state; on the other, with the poses and the expressions already researched in other forms of arts: Performing and Visual.Some Murnau's films serve as examples to think about these issues. It is a question of seeking a horizontal interface between philosophy and art, considering its way of coexistence in the period when the cinema did not speak.

\section{KEYWORDS}

BélaBalázs, F.W.Murnau, Cinema, ArtHistory, Aesthetics. 


\section{Introdução}

Em 1924, morando em Berlim, Béla Balázs ${ }^{1}$ escreve e publica em língua alemã Der sichtbare Mensch, cujo título em português é conhecido como O homem visíve $^{2}$, um dos primeiros textos teóricos sobre o cinema. Este artigo examina o ensaio de Balázs em sua abordagem sobre a linguagem do corpo, gestos e expressões faciais, que constituíram uma forma de comunicação com o público no período em que o cinema era mudo. A tese do homem visível constroe-se a partir de duas vias de reflexão: a primeira refere-se ao resgate da linguagem gestual do homem em seu estado original, antes do surgimento da língua falada; a segunda aborda a linguagem do corpo formulada primeiramente pelas artes cênicas e visuais, antes do advento do cinema. Trata-se de um ensaio pouco estudado, pois o debate sobre o cinema toma novos rumos depois da chegada do som, reduzindo as pesquisas com a linguagem da gestualidade.

O homem visível é econômico quanto aos exemplos e, por vezes, quando estes aparecem - como é o caso de dois filmes de F.W. Murnau mencionados por Balázs: Phanton, 1920, e Nosferatu, 1922 - servema outros propósitos que não a questão do corpo. Todavia, é enriquecedor lembrar os filmes de Murnau ao ler Balázs; o que não quer dizer que o filósofo os tinha em mente. A aproximação, por nossa conta, se justifica pelo recorte dessa análise sobre o pensamento de um filósofo e os filmes de um cineasta, ambos atuantes na Berlim de 1920.

Enquanto pensa sobre as artes da tradição ocidental na linguagem do corpo projetada no cinema, Balázs se questiona sobre a gestualidade enquanto língua dos povos primitivos,observando que a raça ${ }^{3}$ passa a ter relevância no cinema. O percurso aqui proposto compreende a apresentação de trechos selecionados da obra de Balázs, de abordagens extraídas dos filmes de F.W. Murnau e de algumas observações sobre a cena cultural da Alemanha dos anos de 1920. Encerra-se o artigo, retomando a questão da raça que em Balázs permanece até seus últimos textos como um problema em aberto. Murnau, em Tabu, 1931, vai à Polinésia trabalhar com atores nativos para narrar uma pequena tragédia dos mares do sul.

\section{O corpo visível}

Victor Hugo, segundo Béla Balázs, dizia que o livro impresso assumiu o lugar das catedrais; pois desde a invenção da arte tipográfica, o rosto humano tornou-se ilegível nas figuras das igrejas. Como a imprensa de livros, o cinematógrafo promove o efeito inverso, dando ao ser humano um novo rosto. Balázs evoca a época das belas-artes anterior à tipografia, como um tempo em que a arte esteve mais próxima da linguagem gestual e das expressões do homem em seu estado original. Esta época compreende desde as iconografias dos povos

\footnotetext{
1Béla Balázs, pseudônimo de Hebert Bauer, 1884-1949, filósofo, crítico, escritor e roteirista de origem judiagermânica, nascido na Hungria.

${ }^{2}$ Escrito em 1923 e publicado em 1924, Der sichtbare Mensch, ainda não foi integralmente traduzido para o português. A introdução do livro está traduzida na antologia A experiência do Cinema, organizada por Ismail Xavier em 1983.

3Seguindo Balázs, usa-se a palavra "raça" para tratar de questões de corpo, gestos e expressões faciais no contexto cultural da linguagem. Trata-se de refutar a "superioridade racial", valorizando a ideia de raça.
} 
primitivos até a fase do Renascimento, sugerindo que entre a invenção da imprensa no século $X V I$ e o advento do cinema na virada para o século $X X$, o homem se afasta do gesto, língua materna da humanidade. A redescoberta dessa linguagem pelo cinema - arte das imagens sequenciais com pequenas variações nas posições dos membros do corpo - possibilita investigar a gestualidade em sua riqueza linguística. Ao fazer o elogio da atriz Asta Nielsen, Balázs lembra que contam-se quinze mil palavras em Hamlet de Shakespeare, mas ainda não somos capazes de avaliar a quantidade de sinônimos de gestos e expressões na atriz que o interpreta no cinema4. Balázs imagina uma cena na qual Asta Nielsen está em seu camarim maquiando-se, entra no set, atua, volta ao camarim e, enquanto tira a maquiagem, "segura a escova como Michelangelo poderia ter segurado o cinzel na sua última noite: é uma questão de vida e morte"(BÁLAZS, 2010, p. 17). Para o filósofo, a atriz, escultora de seu próprio rosto e corpo, é também autora do filme ao lado do diretor.

Em O homem visível, o pensador húngaro estabelece as distinções entre pintura, escultura, teatro, literatura, dança e cinema a partir do material, ou substância, da qual são feitas as obras:

Escultura e pintura retratam seres humanos e, no entanto, obedecem a regras inteiramente diferentes que são, por sua vez, determinadas pelos diferentes materiais com os quais trabalham. $\mathrm{O}$ material da arte cinematográfica, sua substância básica, também é bem diferente do teatro (BALÁZS, 2010, p.17) (tradução nossa). ${ }^{5}$

Balázs propõe que o material do teatro possui duas camadas: o drama e a atuação, sendo que o drama tem um significado fixo preexistente, o qual o diretor terá de enfatizar na montagem, a atuação consiste em interpretar, meramente, o texto original, o qual será julgado pela qualidade. O filme distingue-se do teatro por não oferecer a possibilidade de julgar o trabalho do escritor; aprecia-se neste o trabalho do diretor e dos atores. Entre diretor e atores, a coautoria, na dimensão do teatro e do cinema, os opõe pela diferença entre a maneira de atuar no palco e na tela. No teatro, os gestos e expressões operam como um acompanhamento das palavras; no filme, palavras não asseguram nada e não acompanham palavras, os gestos e as expressões são os ingredientes do filme. Tanto no teatro como no cinema, pode-se identificar uma má interpretação, mas esta é observada em diferentes perspectivas para cada caso. No teatro, a falsa interpretação de uma personagem preexistente soa como má interpretação; no cinema, o erro não se encontra na contradição do texto subjacente, mas sim nas autocontradições das ações. Isto é, um gesto alocado fora da ordem temporal implicita na sequência das ações produz a autocontradição da personagem. Assim, a substância poética do teatro está no texto e na sua interpetação, no filme, a substância é o gesto visível no jogo de luzes e sombras.

Tartüff, ou Tartufo, obra de Murnau a partir da peça de Molière, só seria filmado em 1925, um ano depois da publicação do texto de Balázs. Opera a

\footnotetext{
$\overline{{ }^{4} H a m / e t, 1} 1921$, filme de produção dinamarquesa, dirigido por SvendGade e Heinz Schall, com Asta Nielsen no papel de Hamlet.

${ }^{5}$ No original: Both sculpture and painting depict human beings and yet they obey entirely different rules that are in turn determined by the different material with which they work. The material of film art, its basic substance, is also quite different from that of theatre(BALÁZS, 2010, p.17).
} 
proposta de um filme dentro de outro filme, no qual as personagens do prólogo e epílogo assistem à projeção do filme Tartufo. Nota-se que, para além do figurino de época do filme central, a maquiagem dos atores é exagerada, assim como gestos e expressões faciais, aludindo ao teatro filmado. Já na história do prólogo e epílogo, as personagens recebem um tratamento mais natural, enfatizando gestos e expressões próprios da linguagem do cinema. Esta obra de Murnau discute as tensões entre as duas artes, teatro e cinema, por meio das histórias paralelas. Diz Balázs que as histórias paralelas apresentam uma intersecção na qual revela-se o sentido mais profundo que não pode ser alcançado por palavras. Para alcançar êxito em sua versão cinematográfica de Tartufo, Murnau trabalha gestos e expressões de modo distintos nas histórias paralelas: o corpo no cinema e o corpo do teatro filmado não usam a mesma linguagem de gestos e expressões, o que faz pensar na tese de Balázs sobre a ideia de que linguagem do corpo no cinema esta mais próxima da linguagem gestual do homem em seu estado original, quando este não havia constituído a língua falada. Já o teatro, mesmo quando dispensa as palavras, usa a linguagem do corpo de modo adequado ao seu espaço cênico.

Neste período, entretanto, o sentido mais superficial também não poderia ser alcançado pelas palavras no cinema. Alguns diretores de teatro, desejosos de ver suas montagens teatrais transformadas em filme sem perder a pureza dos diálogos, aguardavam a chegada do som para que este se colocasse a serviço do teatro filmado. Por outro lado, os diretores de cinema e atores especializavam-se na interpretação gestual e facial diante das câmeras, articulando não só histórias paralelas, mas paralelismos de destinos das personagens em seus encontros e desencontros, paralelismos de imagens na perspectiva das metáforas, paralelismos temporais e espaciais e os mais diversos recursos de linguagem, operando como semântica do filme. Toda essa gramática visual em movimento constrói-se atrelada a detalhes do gesto que vão desde a intenção do corpo no breve movimento de rotação do torso ao olhar que se move debaixo para cima.

Se a linguagem do corpo no teatro, não é suficiente para explicar o corpo mudo do cinema em sua "fala" compreendida pelo público, é preciso investigar outras artes cênicas. Em Balázs, a dança, apesar de ser uma arte fundada na linguagem do corpo, não atinge o andar, os gestos e as expressões faciais das pessoas em seu dia-a-dia; trata-se de uma linguagem gestual ornamental. Balázs lembra o exemplo da dançarina americana Ruth Saint Denis que se consagrou por suas atuações com ênfase na gestualidade da cultura oriental, apresentando espetáculos a partir de cenas egípcias e indianas. Mas a dança, afirma Balázs, é uma arte que opera no sentido das belas poses de estátuas e galerias: a arte da dança não entra no material ordinário da vida das pessoas, só a cultura visual fornece formas expressivas para a nossa relação com o outro, e esta é uma tarefa a ser realizada pelos filmes. A gestualidade do ator de tela está tão longe da gestualidade da dança quanto do teatro; no teatro, gestos e expressões acentuam as palavras, na dança, a linguagem gestual é decorativa. Ao comentar o erotismo de Asta Nielsen, Balázs dedica um parágrafo para compará-la com a dançarina e atriz Anita Berber, famosa por suas apresentações eróticas em teatros e casas noturnas de Viena. Anita participa de alguns filmes, representando, o mais das vezes, personagens próximas à sua vida real: dançarina de cabaré, bissexual, 
andrógina em filme de ficção científica e o papel de Giulia Farnese, a astuta amante de cardeal em Lucrezia Borgia ${ }^{6}$. Para Balázs, o mérito erótico de Asta Nielsen reside nos olhos que brilham e na boca torcida em um corpo de magreza abstrata; ela não mostra sua coxa, sua carne como Anita:

[...] a ponto de ser difícil distinguir entre o rosto e o traseiro e, ainda assim, essa personificação dançante do vício teria muito a aprender com Asta Nielsen. Apesar de sua dança do ventre, ela é uma ovelha inocente ao lado de Nielsen em suas roupas. Pois Nielsen é capaz de parecer uma revelação obscena e tem um jeito de sorrir que poderia muito bem justificar o confisco do filme pela polícia como pornografia. Este erotismo espiritualizado é perigosamente demoníaco, pois seus efeitos não são diminuídos pela roupa (BALÁZS, 2010, p. 87-88) (tradução nossa). ${ }^{7}$

É interessante adentrar no cenário cultural da Berlim dos anos 1920 para melhor compreender o pensamento de Balázs. Na Alemanha, os filmes de cabaré acabarão por se consagrarem como um dos gêneros de maior interesse do público nos anos entre guerras, marcados pela magnífica atuação de Marlene Dietrich em Der Blaue Angel, ou O anjo azul, 1930, dirigido por Josef von Stemberg. Antes disso - e antes mesmo de Balázs escrever O homem visível em 1924 -observa-se um nó atando a linguagem do corpo, pela via da escultura e da dança,e projetando-se na linguagem do corpo no cinema. Como dito no parágrafo anterior, Balázs entende que a dança é "uma arte que opera no sentido das belas poses de estátuas e galerias" e o que ocorre na linguagem do corpo no cinema é outra coisa. No entanto, o caminho para compreensão da nova linguagem, passa pelo exame da dança e das artes visuais vivenciados nos cabarés e espaços alternativos de Berlim. Os espetáculos vivants, isto é, encenações a partir de esculturas, mas também de iconografias ou pinturas que estavam na moda desde a Belle Époque, são encenados por dançarinas de prestígio clássico e por atrizes com conhecimentos básicos de dança, privilegiando inicialmente os temas relacionados à Antíguidade ou à primitividade, passando aos poucos, a apresentar personagens andróginas, extraterrestres e robôs do futuro ${ }^{8}$, que se movem da posição hierática para a leveza, ou vice-versa, lentamente ou aceleradamente. Os artistas investigam as possibilidades de posições e movimentos dos corpos, motivados pelas pesquisas com recursos da fotografia e dos animatógrafos que surgem em meados do século XIX.Considerado um gênero menor de artes cênicas, os espetáculos vivants encontram restrições nos palcos tradicionais da República de Weimar e são levados aos salões privados, feiras de variedades, teatros menores ou cabarés, como dança

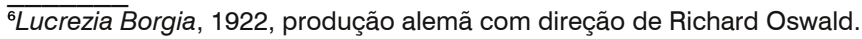

${ }^{7} \mathrm{No}$ original: $[\ldots]$ to the point where it is difficult to distinguish between face and backside, and yet that dancing personification of vice might be able to learn a lot from Asta Nielsen. Notwithstanding her belly dances, she is an innocent lamb by the side of Nielsen in her clothes. For Nielsen is able to look like an obscene revelation and she has a way of smiling that might well justify the police in confiscating the film as pornography. This spiritualized eroticism is so dangerously demonic because its effects are not diminished by clothing(BALÁZS, 2010, p. 87-88).

${ }^{8}$ Metrópolis, 1927, filme alemão de ficção cientfíca, dirigido por Fritz Lang, aproxima-se dos espetáculos de dança na perspectiva futurista das protagonistas interpretadas pela mesma atriz Brigitte Helm: Maria, uma dançarina de cabaré e Falsa Maria, uma máquina humana.
} 
ou espetáculo, onde a mudez e a nudez das obras de mármore, de iconografias primitivas ou de figuras robotizadas, podem apresentar-se operando no embaralhamento do erótico com o pornográfico, do passado com o futuro, da arte com a vida. Anos mais tarde, os teóricos entendem as experiências do período que compreende as "vanguardas modernistas" como embrionárias do que hoje é chamado de performance (GOLDBERG, 2006). Tratava-se, naquele tempo, de inventar novos gêneros de dança, tanto na perspectiva da dança clássica primitivista a exemplo de Ruth Saint Denis, como na dança experimental, vide a andrógina Anita Berber.

Outra dançarina de Berlim, Olga Desmond, é aclamada "Vênus da Prússia", bailarina clássica que se dedica a atuar nua dando vida às poses de esculturas antigas em seus espetáculos e filmes, recaindo nela as acusações de atentar contra os bons costumes por atuar nos limites da pornografia. Se a distinção entre arte erótica e pornográfica nunca foi consensual entre teóricos, para o público também não. Assim como nas artes cênicas, o cinema erótico torna-se um sucesso e, ao mesmo tempo, sofre censuras na Europa: liberava-se em uma cidade, proibia-se em outra $^{9}$. Em Berlim, não por acaso, os filmes de Olga Desmond são realizados entre 1915 e 1919: o cinema erótico fica liberado durante a Guerra, mas ao final desta, as forças conservadoras se impõem favorecendo a censura. Conhecida por sua arte de lebendes Bild, ou living pictures, ou tableaux vivants, Olga escandaliza o mundo percorrendo alguns países da Europa com o seu espetáculo mais famoso, Schönheitsabende, ou Noites de beleza, por vezes censurado pelo fato de os atores despirem-se em público, encenando as poses das esculturas. Encenações do banho das Ninfas, Vênus e Diana tiveram destino semelhante: o sucesso de público seguido do fechamento dos teatros onde eram apresentadas as encenações. $O$ trabalho de Olga rendeu-lhe oito filmes, sendo que um deles intitulava-se Der Mut zur Sünde, A coragem de pecar, e o último Göttin, Dirne und Weib, Deusa, prostituta e mãe. Os títulos, por si, apontam as dificuldades de serem aceitos como arte, situando-os nas fronteiras entre o erótico e o pornográfico. Uma foto de Olga Desmond, posando como Afrodite em um cartão postal de São Petersburgo (Figura 2), exemplifica como a moda dos espetáculos de esculturas vivas conquistou também os fotógrafos da época, levando a dançarina alemã a ser tema de souvenir na Rússia. Na foto do cartão postal, Olga encena uma escultura de Vênus no banho, na qual a personagem acaba de descobrir-se do pano para descer às termas e banhar-se: clássica pose das esculturas da deusa do amor em suas versões de Vênus ou Afrodite. Uma breve comparação entre a foto de Olga e as esculturas antigas de Vênus no banho nos aproxima das relações entre as esculturas em mármore e a escultura vivante, contribuindo para adiante entendermos como a fusão de linguagens de poses escultóricas e de dança alcança o cinema.

\footnotetext{
$\overline{{ }^{9} \mathrm{Em} \text { Viena }}$, o Atelier Saturn-Film do fotógrafo Johann Schwarzer ${ }^{9}$ chegou a produzir mais de 20 filmes eróticos só em 1907, distribuindo suas produções para vários países até ser obrigado a encerrar suas atividades em 1911 por pressão dos estúdios de Paris e Berlim que não conseguiam competir com a ousadia dos filmes eróticos austríacos, conforme o documentário Saturn films: O começo da cinematografia erótica austríaca, youtube: https://www.youtube.com/watch?v=b5XMrlZh7ks
} 

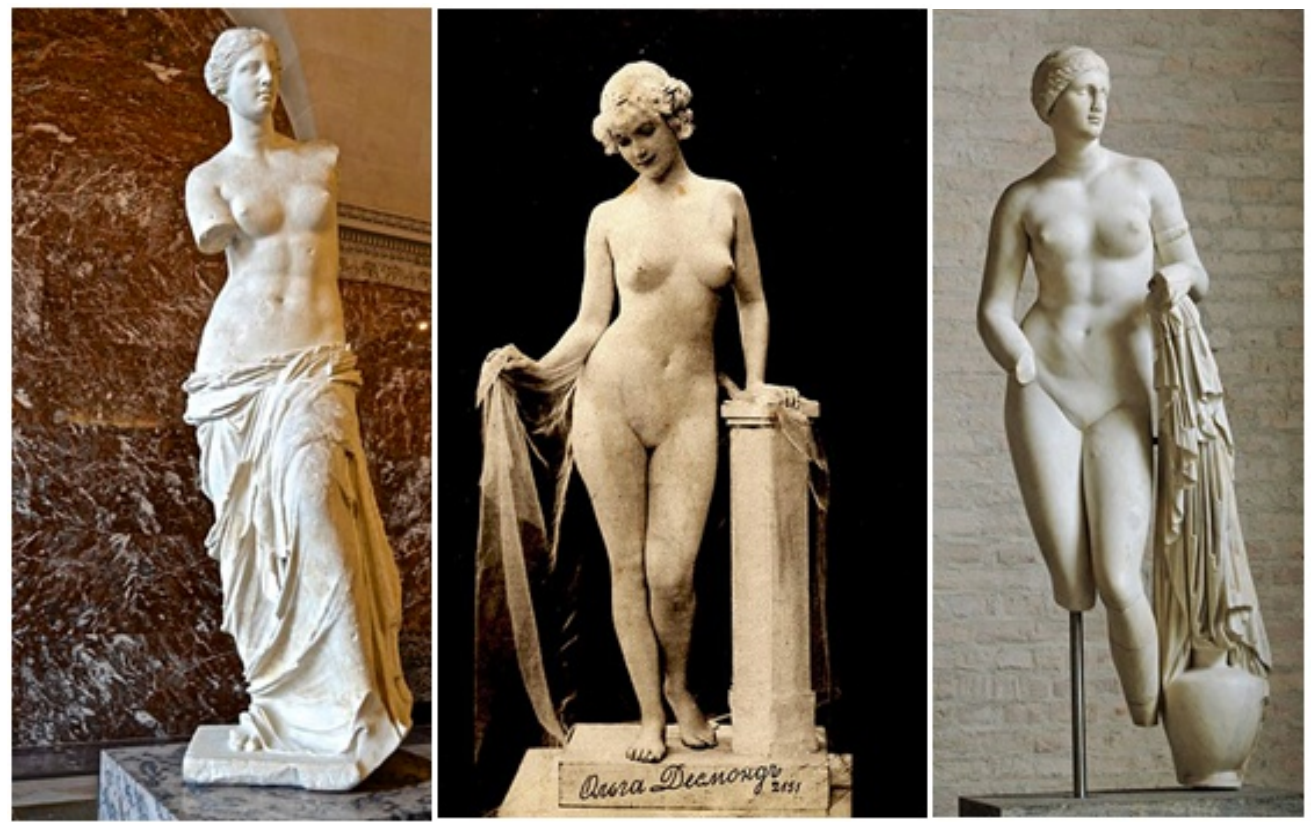

Figura 1. Vênus de Milo. Séc. II AEC - Museu do Louvre. [Wikicommons: Domínio público]. ${ }^{10}$

Figura 2. Olga Desmond, 1907-1908. Cartão postal St. Petersburgo [Wikicommons: Domínio público]. ${ }^{11}$

Figura 3. Afrodite Braschi. Séc. I AEC - Gliptoteca de Munique. [Wikicommons: Domínio público]. ${ }^{12}$

A montagem de fotos leva a supor que a atuação de Olga (Figura 2) começa ou passa pela famosa pose da Vênus de Milo (Figura 1), com o pano ainda enrolado no corpo e segue descobrindo-se deste até chegar à pose da Afrodite Braschi (Figura 3).

No estudo de Afrodite Braschi (Figura 3) e de Olga Desmond (Figura 2), nota-se que ambas já podem ser vistas nuas na parte inferior do corpo. Na escultura de mármore, a alusão ao banho é feita pelo pano que, pendurado no braço direito, estende-se até um vaso posicionado ao lado do pé direito da deusa. Na foto da escultura vivante, a Vênus de Olga acaba de descobrir-se do pano mostrando a parte inferior do seu corpo; o braço direito de Olga indica o movimento de quem segura uma ponta do pano com a mão direita e acaba de abri-lo, mantendo a outra ponta presa entre a mão esquerda e o topo da meia coluna. Em ambas as esculturas, a de mármore e a vivante, o quadril direito está levemente inclinado para cima e apoiado sobre a perna direita que está esticada, enquanto o quadril esquerdo apresenta-se relaxado e a perna esquerda mostra o joelho levemente flexionado. Na Vênus de Olga, o calcanhar está suspenso e o pé esquerdo apoiado na altura dos metatarsos e dedos; na Afrodite Braschi, as pernas estão incompletas, mas é possível supor uma reconstrução imaginária semelhante à posição que é

\footnotetext{
$\overline{1^{\circ} \text { Link para ver: }}$

https://commons.wikimedia.org/wiki/File:The_legendary_Venus_de_Milo_in_the_Louvre,_9_February_2014_crop ped.jpg

${ }^{11}$ Link para ver: https://commons.wikimedia.org/wiki/File:Tableau_vivant_by_Olga_Desmond._01.jpg

12Link para ver: https://commons.wikimedia.org/wiki/File:Aphrodite_Braschi_Glyptothek_Munich_258.jpg
} 
vista na foto de Olga Desmond. Na réplica escultórica, o pano tem dupla função: sustentar o peso do corpo em mármore, ligando o braço ao vaso apoiado no piso e narrar a história do banho da deusa. Na escultura vivante, a posição de Olga em composição com os elementos cênicos, como o pano, está a serviço da memória da obra escultórica. Em ambas as esculturas - Braschi e Olga Desmond - o erotismo se manifesta porque a deusa expõe seu sexo sugerindo que acaba de desenrolar-se do pano. É notável o trabalho de investigação de poses escultóricas feito pela bailarina e coreógrafa Olga. E este é apenas um caso entre tantos experimentos feitos com pinturas, esculturas, arte primitiva ou futurista, vivenciados por artistas, atores e bailarinos em seus corpos, seja em espetáculos cênicos ou levados ao cinema, instigados pela mudez do filme neste período.

O interesse do cinema pela escultura de Vênus remonta pelo menos a 1898, quando Robert W. Paul filmou Come along, do! (Figuras 4 e 5), um filme de aproximadamente um minuto com dois planos.

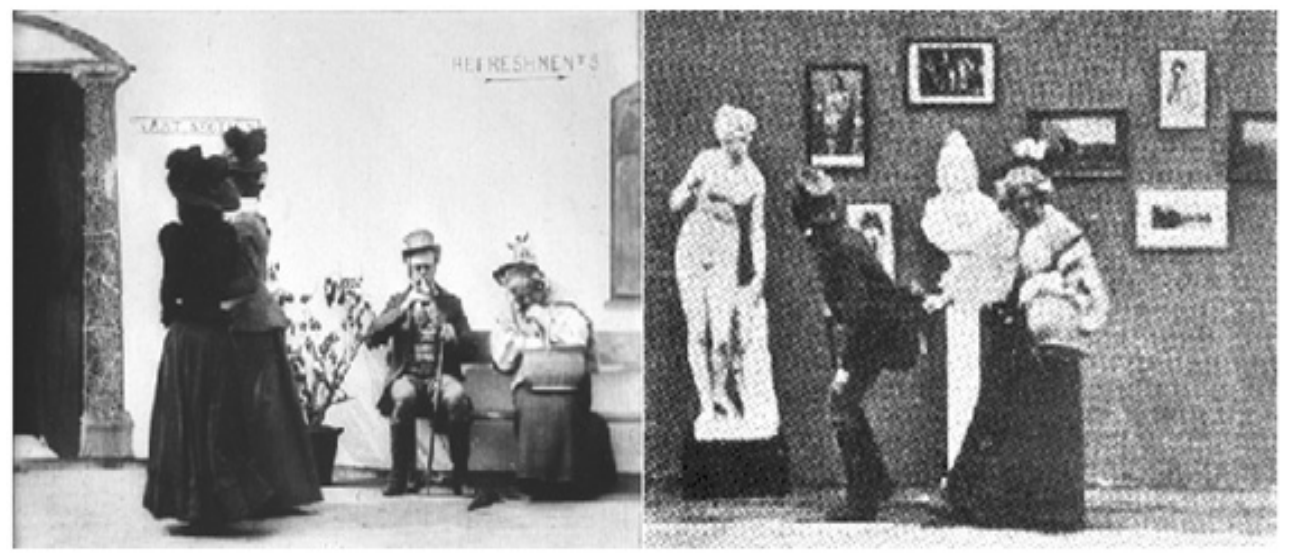

Figuras 4. Fragmento de Come along, do!, 1898, de Robert W. Paul. [Youtube: Domínio público. $]^{13}$

Figuras 5. Fragmento de Come along, do!, 1898, de Robert W. Paul. [Youtube: Domínio público.]

No primeiro plano, um casal de velhos está sentado em um banco em frente a um museu, comendo um lanche e tomando vinho; no segundo plano, o casal está dentro do museu, enquanto a mulher admira alguns quadros, o velho bêbado olha com espanto a escultura de uma Vênus no banho confundindo-a com uma mulher nua. Aludindo ao efeito do vinho sobre a visão, o cinema reafirma sua tarefa de dar vida a seres imóveis. Na época, uma sorte de mania de Pigmalião atinge os cineastas que, valendo-se da moda de esculturas vivantes, exploram o tema, especialmente em filmes eróticos como os de Olga Desmond, infelizmente perdidos, ou como se pode ver no filme $O$ sonho do escultor (Figura 6), de Johann Schwarzer, realizado em 1907.

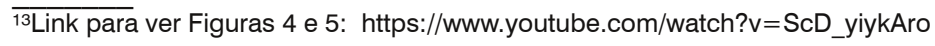




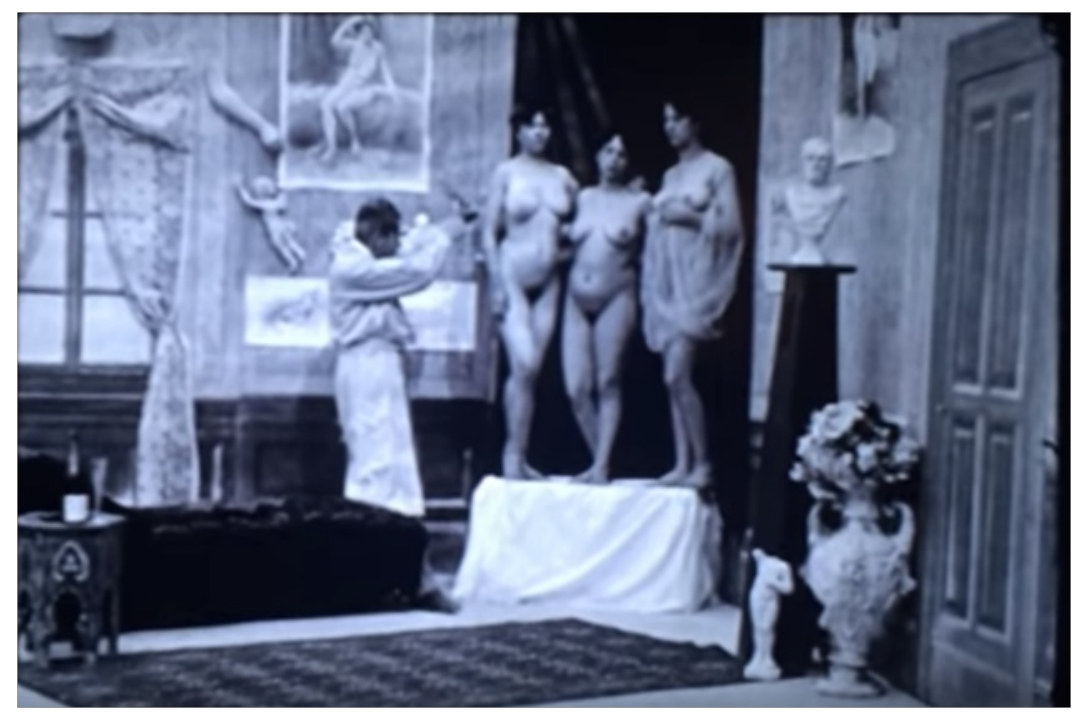

Figura 6. Fragmento de Der Traum des Bildhauers, O sonho do escultor, 1907, de Johann Schwarzer. [Youtube: Domínio público] ${ }^{14}$

Este filme ocorre em uma única tomada de aproximadamente quatro minutos. O escultor de As três graças termina sua obra, fuma, bebe, deita-se e dorme; as figuras escultóricas ganham vida e dançam em torno dele; ao acordar, elas já retornaram à posição inicial. No filme de 1898, a escultura de mármore é objeto diegético ganhando vida apenas na visão comprometida do bêbado. Como a cena "As três graças" é um tema clássico envolvendo uma dança, em 1907, atrizes, possivelmente bailarinas, interpretam hieráticas a conhecida escultura de mármore, ganhando movimento no sonho do escultor. Assim, o jogo entre a pose escultórica e a coreografia participa da construção da linguagem corporal no cinema.

No campo teórico, O homem visível traz o exemplo da Vênus para falar do rosto do homem na arte e na vida. Para Balázs, hoje conhece-se apenas a superfície dos rostos, posto que nossos corpos estão cobertos de roupas, só eventualmente, as mãos com a melancolia de fragmentos mutilados vêm em nosso auxílio:

Mas nos ombros de um torso grego sem cabeça pode ver-se claramente, mesmo nós podemos ainda vê-lo, se o rosto perdido chorava ou ria. As ancas de Vênus não sorriem menos expressivamente do que o seu rosto, e lançar um véu sobre a sua cabeça não seria suficiente para nos impedir de saber o que ela pensa e sente. Pois o homem era visível em todo o seu corpo (BALÁZS, 2010, p. 10) (tradução nossa)..$^{15}$

A evocação da figura da Vênus mutilada que sorri com suas ancas articula-

\footnotetext{
14Link para ver: https://www.youtube.com/watch? $v=4$ Eq_7OQBRrE\&t $=36$ s\&has verified $=1$

${ }^{15}$ No original: The back of a headless Greek torso always reveals whether the lost face was laughing or weeping we can still see this clearly. Venus's hips smile as expressively as her face, and casting a veil over her head would not be enough to prevent us from guessing her thoughts and feelings. For in those days man was visible in his entire body(BALÁZS, 2010, p. 10).
} 
se com a ideia de que o corpo todo está presente nas partes da obra escultórica, o mesmo ocorre no cinema. Todavia, a escultura de mármore não é suficiente para construir a linguagem gestual e expressões faciais no cinema. Em outro momento, falando sobre suas expectativas com a chegada do filme colorido, Balázs reforça a associação entre escultura e cinema, na visada da imitação da natureza cuja verossimilhança só é alcançada associando-se ao colorido.

[...] a fidelidade à natureza nem sempre é benéfica para a arte. As figuras de cera são geralmente tão reais que as pessoas dizem "perdão" quando, inadvertidamente, encostam-se nelas. Mas ninguém dirá que elas são mais artísticas do que as estátuas de mármore branco ou avermelhadas, ou do que as figuras de bronze marrom. A arte consiste na redução. $E$ não é concebível que o cinza homogêneo no cinza do filme atual contenha o segredo de um verdadeiro estilo artístico? (BALÁZS, 2010, p. 78) (tradução nossa)? ${ }^{16}$

O filme preto e branco com matizes de cinzas no jogo de luzes e sombras associa-se à escultura de mármore ou bronze, enquanto o colorido que está por vir $^{17}$ no cinema associa-se ao realismo das figuras de cera. Este comentário ecoa o ano de 1924 quando é lançado Das Wachsfigurenkabinett, O gabinete das figuras de cera, de Paul Leni tido como elogio ao filme preto e branco que nasce como arte provisória aguardando os avanços tecnológicos para a vinda do filme colorido. No entando, as figuras de cera, populares desde a criação do Museu Madame Tussaud no ano de 1835 em Londres, espalhadas como atração em feiras de variedades e exposições itinerantes, participam como personagens de filmes já há algum tempo inclusive na obra de Murnau, contrastando com as personagens escultóricas da Antiguidade.

O cinema, à sua maneira, apreende as experiências artísticas e leva para as telas a temática moral que as permeia ao mesmo tempo em que investiga as linguagens no corpo das personagens escultóricas e pictóricas postas em movimento $^{18}$. Em Der Knabe in Blau, Menino de azul, 1919, filme perdido de F.W. Murnau do qual restam poucos fragmentos, a mocinha é uma atriz que vê sua reputação comprometida por aceitar fazer o papel da Vênus no banho, peça erótica a partir de uma escultura vivante. Já a vilã, é uma boneca de cera programada como robô para realizar uma dança cigana, seduzindo o mocinho. O nome da boneca de cera é Maja, aludindo às obras de Goya, Maja vestida e Maja nua, do final do século XVIII. Ao colocar mocinha e vilã, Vênus e Maja, como personagens da história,

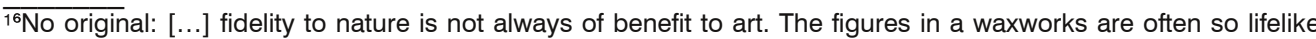
that people say 'I beg your pardon' when they inadvertently brush up against them. But no one will claim that they are more artistic than white marble statues or reddish brown bronze figures. Art actually consists in reduction. And is it not conceivable that the homogeneous grey on grey of the ordinary film contained the secret of a true artistic style(BALÁZS, 2010, p. 78)?

${ }^{17} \mathrm{~A}$ tecnologia de coloração de filmes existe desde os primeiros anos, porém ainda é muito precária nesse período, posto que é aplicada sobre o filme preto e branco. As figuras de cera coloridas se colocam no imaginário dos cineastas como esculturas mais verossímeis do que as personagens em preto e branco, que fazem lembrar o mármore.

${ }^{18}$ No sentido inverso, as artes cênicas e visuais também apreendem as experiências do cinema. Vale lembrar que no ano de 1923, a oficina de teatro da Bauhaus, estreia o espetáculo intitulado O gabinete de figuras I, dirigida por Oskar Schelemmer que assina sua direção com a co-direção de Caligari, aludindo à personagem do filme de Robert Wiene O gabinete do Dr. Caligari, 1920.
} 
Murnau filma as tensões entre erotismo e pornografia na dimensão da linguagem do corpo, gestos e expressões, debatendo a convergência das artes projetadas no cinema. Por outro lado, convoca o espectador a se posicionar a favor ou contra a personagem da mocinha que aceita o papel erótico, a favor ou contra a tecnologia das figuras de cera que podem trazer prazeres ao homem desiludido com a deusa do amor.

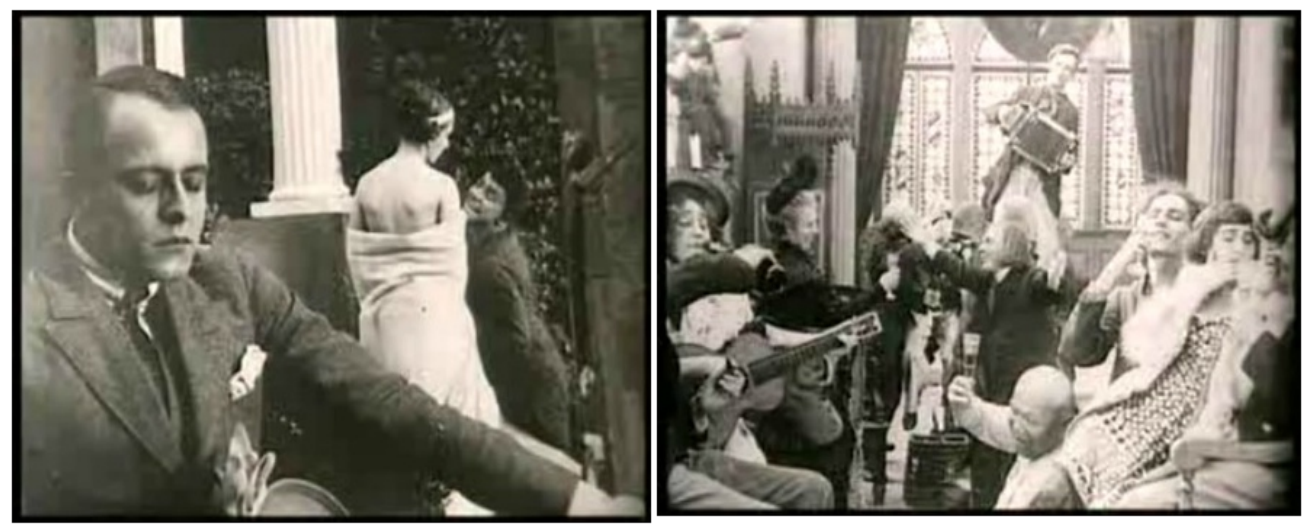

Figura 7. Fragmento de Der Knabe in Blau, Menino de azul, 1919, F.W. Murnau. Margit Baunay

no papel de Lisa Sutroff, a atriz que aceita o convite para encenar Vênus no banho. [Wikicommons: Domínio público] ${ }^{19}$

Figura 8. Fragmento de Der Knabe in Blau, Menino de azul, 1919, F.W. Murnau. Blandine Ebinger, mulher na borda leste da cena, atua no papel de Maja, a figura de cera, alusão as pinturas homonimas de Goya: Maja vestida e Maja desnuda. [Wikicommons: Domínio público $]^{2 \circ}$

As investigações sobre o material sobrevivente em Der Knabe in Blau conduzem a mais hipóteses concernentes às relações entre as artes visuais e o cinema: o mocinho do filme sonha com o retrato intitulado Menino de azul, alusão à obra homônima pintada por Thomas Gainsbourough no século XVIII, em seus passeios visita um museu com esculturas clássicas e também um museu itinerante de figuras de cera, há ainda outra personagem de cera que ganha vida para ajudar os vilões. Nota-se que na práxis do cinema, as relações entre pintura e escultura, esculturas de mármore e de cera, arte do passado e do futuro são personagens, cujos corpos são elementos diegéticos da história narrada. Na medida em que a personagem do mocinho faz suas escolhas rejeitando a mocinha que encena a deusa de mármore na peça erótica e deixando-se seduzir pela figura de cera, a linguagem do corpo media as ações. Isso não diz respeito somente a Murnau, nem à Alemanha: em todos os países por onde a atividade cinematográfica chegava, o mundo das esculturas se movia ${ }^{21}$ de muitas maneiras. A Berlim de 1920 interessouse particularmente pelo tema seja pela escultura de mármore, seja pelas figuras de cera realistas, seja por figuras que aludiam a outros materiais como monstros

\footnotetext{
19Link para ver: https://commons.wikimedia.org/wiki/File:O_garoto_vestido_de_azul_2.jpg

${ }^{2}$ Link para ver: https://commons.wikimedia.org/wiki/File:O_garoto_vestido_de_azul_3.jpg

${ }^{21}$ No Brasil, embora não seja filme do período silencioso, nem o primeiro filme brasileiro que tematiza a escultura, destaca-se o longa-metragem Argila, 1942, de Humberto Mauro, no qual uma mulher rica vive o conflito entre um pretende admirador de esculturas gregas e um artesão da cerâmica marajoara, colocando-se em debate as tensões sociais de classe, o urbano e o rural.
} 
primitivos de lama ou robos futuristas de metal. Tratava-se de trabalhar a composição das personagens de cinema, partindo da linguagem do corpo conhecido das experiências artísticas; mas, igualmente, de refletir sobre as novas abordagens escultóricas advindas das tecnologias de composição mineral, favorecendo a imitação da natureza que colocavam em debate o tema do modelo como engano, ou autoengano, embaralhando vida e arte. Nesse sentido, escultura e cinema confirmavam o antigo sonho de produzir figuras que falam e andam mediadas pelas artes do corpo, ou seja, corpo de atores que alcançam uma elevada expressão gestual e facial; assim, coube ao cinema realizar o sonho da escultura movente.

\section{Considerações finais}

Como dito no início, em 0 homem visível, o debate sobre as artes é entrecortado pelo debate do cinema como linguagem que resgata a gestualidade dos primeiros homens que ainda não sabiam falar. Torna-se pertinente examinar essa questão considerando que este elo está perdido, porém, os povos primitivos sobreviventes guardam gestos e expressões mais próximas do homem em seu estado original do que os povos civilizados. No decorrer do texto, Balázs joga luz aqui e acolá sobre este problema procurando aproximar as experiências de linguagem do corpo no cinema com a linguagem gestual de povos primitivos, e quais relações podem ser estabelecidas com a imagem cinematográfica pela fisionomia dita "racial". Cabe fazer um parêntese para lembrar que este foi um assunto amplo e polêmico na arte cinematográfica, marcado desde 1915 pelo filme The birthy of Nation, ou $O$ nascimento de uma nação, de D.W. Griffith, no qual as personagens afrodescendentes são representadas como selvagens, ignorantes e agressivas por atores brancos com o rosto pintado de preto; black face. Para Balázs, no palco as figuras caracterizam-se por suas palavras, por isso, os atores precisam ser bons intérpretes, mas no filme silencioso, a aparência da raça é primordial:

A capacidade do filme em mostrar como as mudanças nas expressões faciais surgem da natureza da raça, e não da natureza do indivíduo, explica porque filmes com pessoas de outras raças negros, chineses, índios americanos e esquimós - são tão fascinantes [...] Mas o maior mistério aqui é este: como podemos ter sucesso em entender uma expressão facial que nunca vimos antes(BALÁZS, 2010, p. 30) (tradução nossa)??22

Trata-se de uma pergunta à qual Balázs não encontra uma resposta em $O$ homem visível, mas segue investigando na medida em que se aproxima de outro problema: a dominação das imagens pelo homem branco. Se, por um lado, o filósofo afirma que milhões de pessoas frequentam o cinema e aprendem a

\footnotetext{
22No original: The capacity of film to show how changes in facial expressions arise from the nature not of the individual but of the race explains why films with people from other races -Negroes, Chinese, American Indians and Eskimos - are so fascinating [...] But the greatest mystery here is this: how do we succeed in understanding a facial expression that we have never seen before?". (BALÁZS, 2010, p. 30)
} 
linguagem gestual esquecida no tempo; por outro, os povos nativos é que aprendiam a linguagem do corpo branco, aceitando serem dirigidos por estes, usando gestos e expressões de sentimentos de amor, ódio, tristeza ou alegria conforme a cultura dos diretores e roteiristas ocidentais. $O$ tema racial permanece como questão nos textos de Balázs que estão reunidos em Theory of film ${ }^{23}$, publicação inglesa póstuma de 1952. Nesta, o filósofo do cinema afirma que raça e classes sociais encontraram-se no close-up, recurso que se fez necessário para distinguir características próprias de membros de um grupo de mesma fisionômia, conforme demandas narrativas da cultura dominante:

Não houve necessidade de close-ups para nos mostrar os traços típicos comuns das grandes raças coloridas, as fisionomias de grupo reconhecíveis como negros, chineses, esquimós etc. Pelo contrário, esses rostos exóticos pareciam-se todos iguais para nós tão somente porque os conhecíamos superficialmente. Aqui o close-up era necessário para nos mostrar as diferenças individuais entre um chinês e outro, um negro e outro(BALÁZS, 1952, p. 81) (traduçãonossa) ${ }^{24}$.

Em seu último filme, Tabu, 1931, filmado na Polinésia com atores nativos e sem formação profissional, Murnau, mergulha na investigação da imagem dos nativos, delineados pelo jogo de luzes e sombras extraídas dos movimentos da paisagem projetada sobre o close-up de rostos e poses de corpos das personagens nativas, operando como espelho que mostra o outro lado da natureza. O conflito entre raças e classes sociais do arquipélogo é o conflito entre os tabus dos nativos que possuem apenas seus corpos e a cultura dos brancos que domina a produção de imagens cinematográficas.
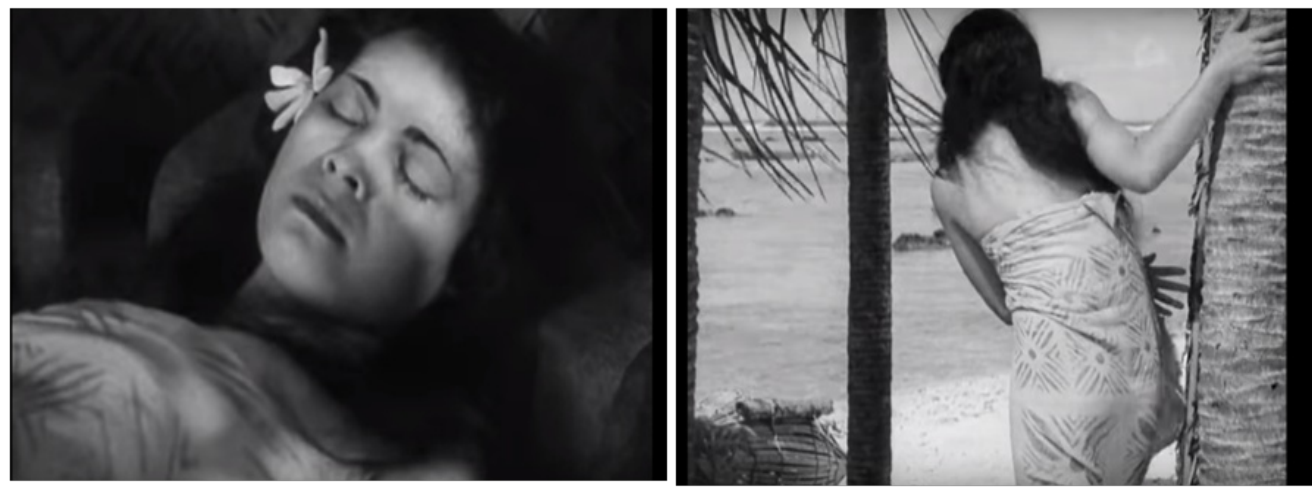

Figuras 9. Fragmento de Tabu, 1931, de F.W. Murnau. [Youtube: DomínioPúbico] ${ }^{25}$ Figuras 10. Fragmento de Tabu, 1931, de F.W. Murnau. [Youtube: Domínio Púbico]

Em uma cena, Reri, personagem cujo papel alude a uma espécie de deusa do amor dos mares do sul, contempla em seu rosto a expressão de uma Vênus

\footnotetext{
23Sem tradução para o português.

${ }^{24} \mathrm{No}$ original: There was no need of close-ups to show us the typical common traits of the great coloureds races, the group physiognomies recognizable as Negro, Chinese, Eskimo, etc. On the contrary these exotic faces seemed all alike to us only because we knew them so superficially. Here the close-up was needed to show us the individual differences between one Chinese and another, one Negro and another. (BALÁZS, 1952, p. 81) ${ }^{25}$ Link para ver Figuras 9 e 10: https://www.youtube.com/watch?v=L_8wlBbYpCl
} 
adormecida, vitimada pelos interesses dos brancos. Em outra, enrolada no pano, Reri inclina o corpo de costas para a câmera, em um gesto de quem pressente a tragédia que está por vir.

\section{Referências}

BALÁZS, B. Theory of the film. Translated from Hungarian by Edith Bone. London: Bristol Typesetting, 1952.

Visible Man. In: CARTER, E. (Ed.). Béla Balázs: Early film theory. Visible Man and The Spirit of Film.Translated by Rodney Livingstone. New York: Berghahn Books, 2010.

DER KNABE IN BLAU. Direção: F. W. Murnau. Produção: Ernst Hofmann. Alemanha, 1919.

EISNER, L. F.W. Murnau. Paris: Le Terrain Vague, 1964.

GOLDBERG, R. A arte da performance -do futurismo ao presente. Tradução Jefferson Luiz Camargo.

São Paulo: Martins Fontes, 2006.

HER TARTÜFF. Direção:F.W. Murnau. Produção: Erich Pommer. Alemanha, 1925.

RUNGE, J. Olga Desmond: Preußens nackte Venus, Frankfourt: Steffen Verlag, 2009.

XAVIER, I. (Org.). A experiência do cinema. Antologia. Rio de Janeiro: Edições Graal, Embrafilme, 1983. (Coleção Arte e Cultura; vol. 5).

TABU, a story of the south seas. Direção: F.W. Murnau e Robert Flaherty. Produção: F.W. Murnau e Robert Flaherty. EUA,1931.

Recebido em 25/05/2019 - Aprovado em 13/11/2019

\section{Como Citar}

Blaud, C. F. (2020). O corpo no cinema silencioso em Béla Balázs e F.W. Murnau. OuvirOUver, 16(1), 202-216. https://doi.org/10.14393/OUV-v16n1a2020-48886

\section{(c) (7) (8)}

A revista ouvirOUver está licenciada com uma Licença Creative Commons Atribuição-NãoComercial 4.0 Internacional. 